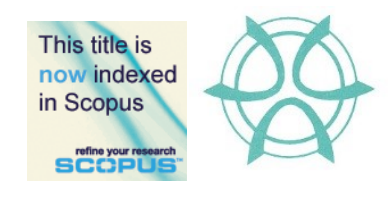

PLANNING MALAYSIA:

Journal of the Malaysian Institute of Planners

VOLUME 18 ISSUE 3 (2020), Page 154 - 166

\title{
EVOLUTION AND DIVERSIFICATION OF MUSEUM \\ FUNCTIONS: A REFLECTION OF MARKET DEMAND IN PENANG, MALAYSIA
}

\author{
Suraiyati Rahman ${ }^{1}$ and Sathish Kumar Velayuthan ${ }^{2}$ \\ ${ }^{1}$ School of Housing, Building and Planning, \\ UNIVERSITI SAINS MALAYSIA \\ ${ }^{2}$ Azman Hashim International Business School, \\ UNIVERSITI TEKNOLOGI MALAYSIA
}

\begin{abstract}
Changes in human values and technological advancements have led to the reinvention of museum interpretation. Studies have shown that the transformation of museums' functions and emerging typology of museums occur globally. Initially, museums' function was to educate society and preserve artefacts for public access, but nowadays, museums have expanded their functions and have become market driven. The increasing number of museum establishments in George Town, Penang has mixed impacts to the curatorship and interpretation of museums. The strategic location of George Town, Penang, its branding as a World Heritage Site, cultural heritage attractions, and local values have gained popularity as a touristic destination. Museums and galleries are the top attractions reviewed by users in TripAdvisor. This article investigates the transformation of functions and typology of museums on the basis of the top 20 museums in Penang listed in TripAdvisor. Content analysis from the secondary data was conducted to establish the pattern and trends of museums' diversification in Penang. Findings revealed that the diversification of museums in Penang has expanded from histories such as natural, science, human, and art to history and art, technology, and specialty. Considering that George Town has been nominated as a World Heritage Site, museums have become consumer-oriented, and private ownership and collaborative partnership have grown drastically. This study contributes by showing that the diversification of museums' function enhances creativity to meet future needs.
\end{abstract}

Keywords: Museums' function, museums transformation, market demand, Penang and eWOM

\footnotetext{
${ }^{1}$ Senior Lecturer at Universiti Sains Malaysia, email: suraiyati@usm.my
} 
PLANNING MALAYSIA

Journal of the Malaysia Institute of Planners (2020)

\section{INTRODUCTION}

The traditional manner of museum interpretation that exposes passive interpretation is no longer aligned with today's society. With the advent of technology, users now prefer 'info-cultural-entertainment' experiences, which combine leisure, entertainment, culture, education and sociability (Hesseldahl, McGinley, \& Monk, 2018; Homadovski, 2009; McCarthy \& Wright, 2005; Stuedahl, D., Lowe, 2013). Nevertheless, museums have become recently popular as cultural attractions, art galleries and monuments. History museums, natural history, sciences, art, technology and virtual museums are examples of museum typology. Recently, consumers are demanding for different museum experiences, such as knowledge and entertainment-based offerings (Chung, Marcketti, \& Fiore, 2014; Del Chiappa, Andreu, \& Gallarza, 2014; Park \& Vargo, 2012). This new demand has led to the transformation of museum functions and diversification, which emphasise on consumers' preferences. Scholars cited issues of changing values of the current generation, which serve as a barrier for the conventional way of museums to appeal to consumers. The advancement of information technology and the influence of electronic word of mouth (e-WOM) influence the current shift experienced by the new type of museums. Privately owned museums and collaborative partnership are competitive in providing services to the market. Thus, museums have shifted to a market-oriented stance, and their new twofold function as knowledge and entertainment hubs has boomed. The present demand, which is influenced by technology-savvy travellers and market orientation, portrays changes in human values. This article attempts to investigate the transformation of functions and typology of museums on the basis of the top 20 museums in Penang listed in TripAdvisor.

\section{LITERATURE REVIEW}

\section{Terminology and Functions of Museums}

The general concept of museums can be traced to ancient Greek civilisation and mythology. A museum is a product and service that is delivered in a physical setting, which takes into account aspects such as building area, shape, lighting, visitor flow, queues, waiting time, crowding and activities that involve engagements (Goulding, 2000). A museum is associated with a non-profit organisation; it is open to the public and acquires, conserves, researches, communicates and exhibits materials or artefacts for education, study and enjoyment' (ICOM definition of a museum 2007). The Department of Museums Malaysia (2016) defined a museum as an institution that is not fixed, non-profit, serves the society and open to the public for educational purposes. The primary function of museums is to educate the public and preserve and protect heritage resources. As a non-profit institution, a museum is essentially formed to heighten 
Suraiyati Rahman and Sathish Velayuthan

Evolution and Diversification of Museum Function: Reflection of Market Demand in Penang, Malaysia

appreciation of cultural values and to instil the value of knowledge among the public.

A museum can be interpreted as a space or building that displays objects or artefacts of historical, artistic or scientific value. One of the aspects that define overall visitors' experience in museums is customer service, which requires interaction between museum staffs and visitors (Sheng \& Chen, 2012). Museums also provide opportunities for self-directed learning for people from different backgrounds and with different abilities. Museums serve as a place for public gathering for entertainment and leisure. As a medium that preserves local identity, a museum protects national, regional and community identity inherited from the past. This function was further acknowledged by Pitman and Hirzy (2004), who stated that museums play an important role in the continuity of inheritance while portraying the progression of human ideas. Therefore, museums function as an entity to enrich local culture, a pillar in disseminating knowledge and a venue for community engagement.

\section{Types and Ownership of Museums}

Various types of museums are found worldwide. Some major categories are historical, natural history, art and science museums. Historical museums play a major role in encouraging appreciation of history and in promoting the value of history for future understanding. Most cities have a diverse categorisation of museums, which are managed by governmental bodies, private companies and both parties. Today, managing museums entails an understanding of the custodial role and the need to attract visitors. Museums are essentially under the non-profit sector and depend on the government for up to 70 percent of financial support; hence, museums should be made competitive by the government by increasing visitor numbers (Gilmore \& Rentschler, 2002). Historic villages or living history museums are other types of historical museums. On the one hand, since their introduction in the late 1970s, interactive-type museums or 'living' heritage museums have been dedicated to Victorian and post-Victorian societal and industrial recreations (Del Chiappa et al., 2014). On the other hand, natural history museums aimed to exhibit natural science and history in transmitting knowledge to society. Today, natural history museums portray various aspects, including a history of biodiversity, ecology, human evolution and animal evolution. Generally, science museums incorporate an interactive approach in interpreting materials to a heterogeneous group of users. This approach uses interactive technologies that give hands-on experiences to visitors while stimulating curiosity for better understanding of science in real-world practice. Art museums reflect historic and modern artistic executions as they allow visitors to appreciate and enjoy the beauty of art works. A current trend is that everything 
PLANNING MALAYSIA

that surrounds us is being 'museumised' for educational heritage (Álvarez, Dávila, \& Naya, 2017).

\section{Technological Advancements and the Influence of Electronic Word of Mouth (e-WOM)}

The advancement of technology has strengthened a shift towards user-friendly museum interpretation that enhances users' experiences. To enhance visitors' experiences and engagement, museums have started adopting the use of information communication and technologies (ICTs) and related features (Giacomo, Luisa and Martina., 2014). Meeting the demands of well-informed and technology-savvy visitors, the interactive interpretation approach of museums reflects the shift from product-oriented to consumer-orientated offerings in this sector.

This shift from a product orientation to consumer orientation has been longer to come for researchers interested in museums than in any other tourism service

(Giacomo, Luisa and Martina., 2014 p.421).

The era of globalisation has attempted the transformation of museum functions, which were initially seen as educational centres that educate people as well as provide social and spiritual experiences through exhibitions and other activities (Ab Samad et al., 2012). The virtual museum combines various forms of interactivity and immersions for educational purposes and enjoyment while enhancing visitor experience (Barbieri, Bruno, \& Muzzupappa, 2017; Koslow, 2019; Schweibenz, 1998). Nowadays, technology and virtual museums generally integrate exhibits with the use of advanced technology to create interactive interpretation. In the digital age era, the Internet has evolved from a broadcast medium to a participatory platform that allows people to become the media themselves as they collaborate and share information. The ability to share information via social media has made substantial changes in information asymmetry and the bargaining power of consumers. According to Ahmed, Ahmad, Ahmad and Zakaria (2019), social media has fundamentally changed the consumer decision process, and a complex view of how consumers engage with brands has emerged in the last decade. The usage of smartphones with highquality built-in camera has led to an increase in the sharing of museum experiences among consumers (Weilenmann, Hillman, \& Jungselius, 2013). In addition, Shaharir and Zanuddin (2018) pointed out that museums should emphasise impactful communication strategies, such that social media, rather than solely depending on official websites, can be utilized for audience interaction. 
Suraiyati Rahman and Sathish Velayuthan

Evolution and Diversification of Museum Function: Reflection of Market Demand in Penang, Malaysia

\section{METHODOLOGY}

A content analysis technique based on secondary data was conducted to examine the evolution of museum functions and diversification of types in Penang, Malaysia. Content analysis requires a systematic reading of texts or images that refer to codes to identify an emerging pattern that reflects meaningful content (Denzin \& Lincoln, 2006, 2008). The data were sourced from previous literature related to museums in Penang, museum websites and TripAdvisor. Consumer reviews from top 20 museums in Penang listed in TripAdvisor were extracted. A cut-off date is set until 20 May 2020 in obtaining the top 20 museums to obtain the total reviews and star rating. The technique used is important in objectively and systematically examining the characteristics of museums according to their respective websites. The codes were extracted on the basis of the research objectives, such as the museum name, year of establishment, ownership, functions, location and descriptions. Themes on the typology of the museum were developed according to the descriptions.

\section{FINDINGS AND DISCUSSION}

\section{Types and Functions of Museums in Penang before being Nominated as a} World Heritage Site

George Town has a total of approximately 5,000 premises, which is the largest collection of pre-war premises in Southeast Asia. The conservation of historic buildings has become one of the approaches to prevent deterioration and to safeguard heritage buildings. Since the nomination of George Town as a World Heritage Site, the creative economy has grown tremendously in the inner city of George Town. As a part of the creative economy, privately owned museums have become an emerging business sector in George Town. In 1941, the first establishment of a museum in Penang was initiated, but it was a failed attempt due to the Japanese colonisation. Later, the Penang Museum and Art Gallery was opened on 14 April 1965 by the state governor (Ahmad, 2015). The Penang State Museum and Art Gallery has a collection of 300 displays for public viewing. In addition, the University Museum was established in 1982 to focus on natural history and science. This museum is renowned for its archaeological experts, technological advancements and their interesting programmes like 'Night in the Museum'. Table 1 presents the types of museums, year of establishment, ownership, location and primary features of exhibits. Since 1965, only nine museums were established before the inscription of George Town as a World Heritage Site. Before 2008, the museums mainly focused on history, art, natural history and science. 
Table 1: Types and Key Features of Museums in Penang before 2008

\begin{tabular}{|c|c|c|c|c|}
\hline $\begin{array}{l}\text { Name of } \\
\text { Museum }\end{array}$ & $\begin{array}{l}\text { Establishment } \\
\text { and Ownership }\end{array}$ & Type & Location & Features \\
\hline $\begin{array}{l}\text { 1.Penang State } \\
\text { Museum and } \\
\text { Art Gallery }\end{array}$ & $\begin{array}{l}1965 \\
\text { (State) }\end{array}$ & History & $\begin{array}{l}\text { Farquhar } \\
\text { Street, } \\
\text { George } \\
\text { Town }\end{array}$ & $\begin{array}{l}\text { Exhibits the history of the city, } \\
\text { formations, culture of various races, } \\
\text { colonial artefacts and population } \\
\text { history. }\end{array}$ \\
\hline $\begin{array}{l}\text { 2.Museum and } \\
\text { Gallery Tuanku } \\
\text { Fauziah }\end{array}$ & $\begin{array}{l}1982 \\
\text { (University) }\end{array}$ & $\begin{array}{l}\text { Natural } \\
\text { History \& } \\
\text { Science }\end{array}$ & $\begin{array}{l}\text { Minden } \\
\text { Campus, } \\
\text { USM }\end{array}$ & $\begin{array}{l}\text { Holds the finding on Perak Man in } \\
\text { Lenggong Valley. Renowned for } \\
\text { Archaeology, Sciences, Ethnography, } \\
\text { Technology and Astronomy. }\end{array}$ \\
\hline $\begin{array}{l}\text { 3.Penang } \\
\text { Forestry } \\
\text { Museum }\end{array}$ & $\begin{array}{l}1983 \\
\text { (Forestry } \\
\text { Department) }\end{array}$ & $\begin{array}{l}\text { Natural } \\
\text { History \& } \\
\text { Science }\end{array}$ & $\begin{array}{l}\text { Telok } \\
\text { Bahang }\end{array}$ & $\begin{array}{l}\text { Home for all the information on the } \\
\text { jungle, daily usage of woods \& its } \\
\text { industry in Penang, flora \& fauna and } \\
\text { related natural resources. }\end{array}$ \\
\hline $\begin{array}{l}\text { 4.Penang } \\
\text { Islamic Museum }\end{array}$ & $\begin{array}{l}1995 \\
\text { (Private) }\end{array}$ & History & $\begin{array}{l}\text { Acheen } \\
\text { Street, } \\
\text { George } \\
\text { Town }\end{array}$ & $\begin{array}{l}\text { Exhibit the Islamic Culture, Leaders, } \\
\text { Architecture, Islamic Education and } \\
\text { related believes practised in Penang }\end{array}$ \\
\hline $\begin{array}{l}\text { 5.P.Ramlee } \\
\text { Gallery }\end{array}$ & $\begin{array}{l}2002 \\
\text { (National } \\
\text { Achieves) }\end{array}$ & $\begin{array}{l}\text { Speciality } \\
\text { (History) }\end{array}$ & $\begin{array}{l}\text { Perak } \\
\text { Road, } \\
\text { George } \\
\text { Town }\end{array}$ & $\begin{array}{l}\text { Exhibits the real-life history of the } \\
\text { actor, film and musical practices and } \\
\text { other involvement by the actor }\end{array}$ \\
\hline $\begin{array}{l}\text { 6.Penang War } \\
\text { Museum }\end{array}$ & $\begin{array}{l}2002 \\
\text { (Private) }\end{array}$ & History & $\begin{array}{l}\text { Batu } \\
\text { Maung }\end{array}$ & $\begin{array}{l}\text { Exhibits military motorcycles, military } \\
\text { intelligence room, Gun and used } \\
\text { cartridges, Japanese torture rooms and } \\
\text { weapons, war replicas and related } \\
\text { photos. }\end{array}$ \\
\hline $\begin{array}{lr}7 . \text { Khoo } & \text { Kongsi } \\
\text { Museum } & \text { and } \\
\text { Gallery } & \end{array}$ & $\begin{array}{l}2002 \\
\text { (Private) }\end{array}$ & $\begin{array}{l}\text { History } \\
\text { and Art }\end{array}$ & $\begin{array}{l}\text { Lebuh } \\
\text { Cannon, } \\
\text { George } \\
\text { Town }\end{array}$ & $\begin{array}{l}\text { The clan temple that retained its } \\
\text { authentic character in the late } 19^{\text {th }} \\
\text { century. It includes association } \\
\text { building, traditional theatre and clan } \\
\text { houses. }\end{array}$ \\
\hline $\begin{array}{lr}\text { 8.i-box } & \text { Glass } \\
\text { Museum } & \text { Penang }\end{array}$ & $\begin{array}{l}2006 \\
\text { (Private) }\end{array}$ & Art & $\begin{array}{l}\text { Jalan } \\
\text { Burma }\end{array}$ & $\begin{array}{l}\text { Portrays decorative glass artworks and } \\
\text { paintings as a reflection of people's } \\
\text { lifestyle. }\end{array}$ \\
\hline $\begin{array}{l}\text { 9.Sun Yat-Sen } \\
\text { Museum }\end{array}$ & $\begin{array}{l}2006 \\
\text { (Private) }\end{array}$ & $\begin{array}{l}\text { History } \\
\text { and Art }\end{array}$ & $\begin{array}{l}\text { Armenian } \\
\text { Street }\end{array}$ & $\begin{array}{l}\text { A beautifully preserved house of Sun } \\
\text { Yat Sen's historic period. Original } \\
\text { features, furniture's, house fixtures } \\
\text { and ancient landscapes. }\end{array}$ \\
\hline
\end{tabular}

Source: TripAdvisor and other websites 
Suraiyati Rahman and Sathish Velayuthan

Evolution and Diversification of Museum Function: Reflection of Market Demand in Penang, Malaysia

\section{Diversification of Museum Typology and Function after the Nomination of George Town as a World Heritage Site}

As shown in Table 2, museum trends have evolved in Penang. After the nomination of George Town as a World Heritage Site in 2008, more than 30 museums have opened, the majority of which are privately owned. Table 2 shows that the number of museums that focus on art, specialty, history and technology has increased drastically. From 1965 to 2018, a total of 7 museums are categorised under art, followed by 5 museums under history, 4 museums under history and arts, 2 museums under natural history and science, 2 museums under technology and 2 museums and gallery under category specialty. Today, most museums in Penang are focused on the arts, whereas earlier museums focused on history, natural history and science. Knowledge-focused and interactive or leisure-based offerings started to emerge due to consumer demand. A similar pattern was noted by Giacomo, Luisa and Martina (2014), in which museums have started adopting interactive features and technology to enhance visitors' experiences and engagement. Examples of such technology-based museums are Penang Camera Museum, Asia Camera Museum and Tech Dome Penang. These museums and galleries portray the transformation of technology innovation in curatorship. Secondly, the evolution of museums in Penang has notably added value in leisure, education and cultural preservation, which is aligned with the need for knowledge and entertainment offerings (Álvarez et al., 2017; Lee, 2010; Volkert, 2019). The development of consumer-oriented products (Brännback, 1999), customer orientation and 'total customer care' will provide superior value to customers, which leads to success in the global competition.

\section{Private and Collaborative Ownership of Museums}

Table 2 shows that the number of museums has increased drastically, and the majority are profit organisation museums that focus on art museums. The transformation of the museum has changed in terms of function and ownership. However, the primary role of preservation and exhibition still apply. According to McPherson (2006), the vast changes in the function of museums started in the 20th century due to the new market revolution that concentrated on financial advancements. The market revolution and the new idea of museums in Penang emerged due to its new status as a World Heritage Site and the re-adaptive use of heritage buildings. A prime example is The Peranakan Museum, which was initially a privately owned mansion that showcased various historical collections, cultural traditions and lifestyle and architecture. The museum was reinvented such that it was commodified and transformed into a profitable product. Del Chiappa et al. (2014) noted that this shift from a product orientation to a consumer orientation is particular in museums. The partnership between private companies 
and governmental bodies is evident in newly established museums and galleries, such as Tech Dome and Penang House of Music.

Table 2: Types and Key Features of Museums in Penang after 2008

\begin{tabular}{|c|c|c|c|c|}
\hline $\begin{array}{l}\text { Name of } \\
\text { Museum }\end{array}$ & $\begin{array}{l}\text { Establishmen } \\
\text { t and } \\
\text { Ownership } \\
\end{array}$ & Type & Location & Features \\
\hline $\begin{array}{l}\text { 1.Penang } \\
\text { Peranakan } \\
\text { Museum }\end{array}$ & $\begin{array}{l}2010 \\
\text { (Private) }\end{array}$ & $\begin{array}{l}\text { History and } \\
\text { Art }\end{array}$ & $\begin{array}{l}\text { Church } \\
\text { Street, } \\
\text { George } \\
\text { Town }\end{array}$ & $\begin{array}{l}\text { The Pinang Peranakan Mansion is a } \\
\text { re-creation of a typical home for } \\
\text { wealthy Peranakan Chinese. Exhibit } \\
\text { extravagant lifestyle and variety of } \\
\text { customs with a collection of } \\
\text { antiques of Peranakan heritage. }\end{array}$ \\
\hline $\begin{array}{l}\text { 2.The } \\
\text { Camera } \\
\text { Museum }\end{array}$ & $\begin{array}{l}2013 \\
\text { (Private) }\end{array}$ & Technology & $\begin{array}{l}\text { Muntri } \\
\text { Street, } \\
\text { George } \\
\text { Town }\end{array}$ & $\begin{array}{l}\text { Portrays collections of vintage } \\
\text { cameras and accessories since the } \\
18^{\text {th }} \text { century. }\end{array}$ \\
\hline $\begin{array}{l}\text { 3. Batik } \\
\text { Painting } \\
\text { Penang } \\
\text { Museum }\end{array}$ & 2013 (Private) & Art & $\begin{array}{l}\text { Armenian } \\
\text { Street, } \\
\text { George } \\
\text { Town }\end{array}$ & $\begin{array}{l}\text { About } 90 \text { Batik Paintings are being } \\
\text { presented in this Museum. Teng's } \\
\text { early works done in the } 1950 \text { s up } \\
\text { until the current period, over } 30 \\
\text { artists are represented. }\end{array}$ \\
\hline $\begin{array}{l}\text { 4.Made in } \\
\text { Penang } \\
\text { Interactive } \\
\text { Museum }\end{array}$ & $\begin{array}{l}2013 \\
\text { (Private) }\end{array}$ & $\begin{array}{l}\text { Art and } \\
\text { technology }\end{array}$ & $\begin{array}{l}\text { Weld Quay, } \\
\text { George } \\
\text { Town }\end{array}$ & $\begin{array}{l}\text { Pooled with the interactive kiosk } \\
\text { and videos, it offers the } 3 \mathrm{D} \\
\text { interactive arts. }\end{array}$ \\
\hline $\begin{array}{l}\text { 5.Asia } \\
\text { Camera } \\
\text { Museum }\end{array}$ & $\begin{array}{l}2014 \\
\text { (Private) }\end{array}$ & Technology & $\begin{array}{l}\text { Lebuh } \\
\text { Armenian, } \\
\text { George } \\
\text { Town }\end{array}$ & $\begin{array}{l}\text { Home for more than } 1000 \text { ancient } \\
\text { cameras and photographic } \\
\text { accessories. History of Photography } \\
\text { and Rare magic lanterns projectors. }\end{array}$ \\
\hline $\begin{array}{l}\text { 6.PENANG } \\
\text { 3D TRICK } \\
\text { ART } \\
\text { MUSEUM }\end{array}$ & 2014 (Private) & Art & $\begin{array}{l}\text { Lebuh } \\
\text { Penang } \\
\text { George } \\
\text { Town }\end{array}$ & $\begin{array}{l}\text { Feature art and painting of } 2 \mathrm{D} \text { and } \\
3 \mathrm{D} \text { as an art hub. }\end{array}$ \\
\hline $\begin{array}{l}\text { 7.Upside } \\
\text { Down } \\
\text { Museum }\end{array}$ & $\begin{array}{l}2015 \\
\text { (Private) }\end{array}$ & Art & $\begin{array}{l}\text { Lebuh } \\
\text { Kimberly, } \\
\text { George } \\
\text { Town }\end{array}$ & $\begin{array}{l}\text { It provides the unique experience of } \\
\text { living upside down and visitors } \\
\text { could enjoy photography session } \\
\text { throughout their exploration. }\end{array}$ \\
\hline $\begin{array}{l}\text { 8.Colonial } \\
\text { Museum }\end{array}$ & $\begin{array}{l}2015 \\
\text { (Private) }\end{array}$ & History & $\begin{array}{l}\text { Jalan D.S. } \\
\text { Ramanathan, } \\
\text { George } \\
\text { Town }\end{array}$ & $\begin{array}{l}\text { Provides the experience on colonial } \\
\text { past, a lifestyle of both British } \\
\text { Administrators, merchants and } \\
\text { other historical leftovers. }\end{array}$ \\
\hline
\end{tabular}


Suraiyati Rahman and Sathish Velayuthan

Evolution and Diversification of Museum Function: Reflection of Market Demand in Penang, Malaysia

\begin{tabular}{|c|c|c|c|c|}
\hline $\begin{array}{l}\text { 9.Penang } \\
\text { Ghost } \\
\text { Museum }\end{array}$ & $\begin{array}{l}2015 \\
\text { (Private) }\end{array}$ & Art & $\begin{array}{l}\text { Lebuh } \\
\text { Melayu } \\
\text { George } \\
\text { Town }\end{array}$ & $\begin{array}{l}\text { Features the horror and myth of all } \\
\text { evils and ghost stories in Malaysia. }\end{array}$ \\
\hline $\begin{array}{l}\text { 10.Penang } \\
\text { Time Tunnel } \\
\text { Museum }\end{array}$ & $\begin{array}{l}2015 \\
\text { (Private) }\end{array}$ & $\begin{array}{l}\text { Art and } \\
\text { History }\end{array}$ & $\begin{array}{l}\text { Jalan Green } \\
\text { Hall, George } \\
\text { Town }\end{array}$ & $\begin{array}{l}\text { Presents the ancient discovery and } \\
\text { old Penang since the year } 1592 \text { via } \\
11 \text { tunnels. }\end{array}$ \\
\hline $\begin{array}{l}\text { 11.Wonder } \\
\text { Food } \\
\text { Museum }\end{array}$ & $\begin{array}{l}2015 \\
\text { (Private) }\end{array}$ & Art & $\begin{array}{l}\text { Lebuh } \\
\text { Pantai, } \\
\text { George } \\
\text { Town }\end{array}$ & $\begin{array}{l}\text { Showcases a variety of food and } \\
\text { beverages locally served. Presents } \\
\text { the larger version of those wonder } \\
\text { foods representing the state as food } \\
\text { heaven. }\end{array}$ \\
\hline $\begin{array}{l}\text { 12.Penang } \\
\text { Gold } \\
\text { Museum }\end{array}$ & $\begin{array}{l}2016 \\
\text { (Private) }\end{array}$ & Art & $\begin{array}{l}\text { Lebuh } \\
\text { Bishop, } \\
\text { George } \\
\text { Town }\end{array}$ & $\begin{array}{l}\text { Features the Gold \& Silver } \\
\text { collections, Gold Panning } \\
\text { Experience, Physical Gold \& Silver } \\
\text { Touching, Live Panning \& } \\
\text { Demonstration, 3-D Murals. }\end{array}$ \\
\hline $\begin{array}{l}\text { 13.Penang } \\
\text { House of } \\
\text { Music }\end{array}$ & $\begin{array}{l}2016 \quad \text { State } \\
\text { Government } \\
\text { and } \\
\text { Perbadanan } \\
\text { Bekalan Air } \\
\text { Pulau Pinang }\end{array}$ & $\begin{array}{l}\text { Art and } \\
\text { Music }\end{array}$ & $\begin{array}{l}\text { Penang Road } \\
\text { (Komtar } \\
\text { Level 2) }\end{array}$ & $\begin{array}{l}\text { Penang's glorious musical heritage } \\
\text { and cultural diversity with carefully } \\
\text { curated exhibitions and interactive } \\
\text { features. Feature on communal } \\
\text { music, a recreation of a radio booth } \\
\text { and cinema. }\end{array}$ \\
\hline $\begin{array}{l}\text { 14.TEDDYVI } \\
\text { LLE } \\
\text { MUSEUM }\end{array}$ & 2016 (private) & Speciality & $\begin{array}{l}\text { Jalan Low } \\
\text { Yat, Batu } \\
\text { Feringghi }\end{array}$ & $\begin{array}{l}\text { Malaysia's first and largest } \\
\text { collection of Teddy Bears from } \\
\text { various nations and eras; as early as } \\
\text { the } 1900 \text { s. }\end{array}$ \\
\hline $\begin{array}{l}\text { 15.TECH } \\
\text { DOME } \\
\text { PENANG }\end{array}$ & $\begin{array}{l}2016(\text { a } \\
\text { collaboration } \\
\text { between State } \\
\text { Government } \\
\text { \& private } \\
\text { sector) }\end{array}$ & $\begin{array}{l}\text { Speciality } \\
\text { (Science and } \\
\text { Discovery } \\
\text { Centre) }\end{array}$ & $\begin{array}{l}\text { Jalan } \\
\text { Penang, } \\
\text { Komtar }\end{array}$ & $\begin{array}{l}\text { Hub for technology learning and } \\
\text { exchange ideas. }\end{array}$ \\
\hline $\begin{array}{l}\text { 16.3D GLOW } \\
\text { IN THE } \\
\text { DARK } \\
\text { MUSEUM }\end{array}$ & 2016 (Private) & $\begin{array}{l}\text { Speciality } \\
\text { (art) }\end{array}$ & $\begin{array}{l}\text { Kimberly } \\
\text { Street, } \\
\text { George } \\
\text { Town }\end{array}$ & $\begin{array}{l}\text { First Glow-In-The-Dark Museum in } \\
\text { Malaysia. The Dark Mansion } \\
\text { appears to be one of the trendiest } \\
\text { modern art museums as it integrates } \\
\text { technology with arts. }\end{array}$ \\
\hline $\begin{array}{l}\text { 17.ASIA } \\
\text { COMIC } \\
\text { CULTURAL } \\
\text { MUSEUM }\end{array}$ & 2017 (Private) & $\begin{array}{l}\text { Speciality } \\
\text { (arts) }\end{array}$ & $\begin{array}{l}\text { Jalan } \\
\text { Magazine, } \\
\text { George } \\
\text { Town }\end{array}$ & $\begin{array}{l}\text { Exhibit the history and } \\
\text { development of comics from the } \\
\text { first beginnings to the present in } 9 \\
\text { Asian countries including Malaysia. }\end{array}$ \\
\hline
\end{tabular}

Source: Multiple websites 


\section{Influence of e-WOM in Marketing Museums}

As shown in Table 3, the recently established museums were listed as top 20 museums in Penang compared with museums established before 2008. The top museum listed in TripAdvisor is Penang House of Music, which was launched in 2016. Although many newly museums were established within less than 10 years, their services and products were shared by users with a high rating on TripAdvisor compared to museums established before 2008. The second top museum in Penang is Penang Peranakan Museum with a total of 4,270 reviews with 4.5 -star rating. The majority of users posted positive comments in terms of museum interpretation, the collection of exhibits, interior architecture and tour guide. Only three museums established before 2008 were included in the top 20 museums in TripAdvisor. These museums are Khoo Kongsi, Sun Yat Sen Museum and Penang State Museum and Art Gallery. Similarly, Li and Wang (2011) mentioned that marketing and promotions have evolved from a broadcasting medium to a participatory platform.

Table 3: Ranking of Museums according to Reviews and Star Rating

\begin{tabular}{|r|c|r|r|r|}
\hline Rank & Name of Museum & $\begin{array}{c}\text { Year } \\
\text { of Est }\end{array}$ & $\begin{array}{c}\text { Numbers of } \\
\text { Reviews }\end{array}$ & $\begin{array}{c}\text { Star } \\
\text { Rating }\end{array}$ \\
\hline 1 & Penang House of Music & 2016 & 210 & 5 \\
\hline 2 & Penang Peranakan Museum & 2010 & 4270 & 4.5 \\
\hline 3 & Colonial Museum & 2015 & 375 & 4.5 \\
\hline 4 & Asia Camera Museum & 2014 & 279 & 4.5 \\
\hline $\mathbf{5}$ & Khoo Kongsi & $\mathbf{2 0 0 2}$ & $\mathbf{1 7 7 4}$ & $\mathbf{4 . 5}$ \\
\hline 6 & Wonder Food Museum & 2016 & 362 & 4.5 \\
\hline 7 & TeddyVille Museum & 2016 & 116 & 4.5 \\
\hline $\mathbf{8}$ & Sun Yat-Sen Museum & $\mathbf{2 0 0 6}$ & $\mathbf{3 6 3}$ & $\mathbf{4}$ \\
\hline 9 & Tech Dome Penang & 2016 & 105 & 4.5 \\
\hline 10 & The Camera Museum & 2013 & 637 & 4 \\
\hline 11 & Upside Down Museum & 2015 & 840 & 4 \\
\hline 12 & Penang Time Tunnel Museum & 2015 & 278 & 4 \\
\hline 13 & Penang 3D Trick Art Museum & 2014 & 540 & 4 \\
\hline 14 & Batik Painting Penang Museum & 2013 & 48 & 4.5 \\
\hline 15 & Penang State Museum and Art Gallery & $\mathbf{1 9 6 5}$ & $\mathbf{2 5 4}$ & $\mathbf{4}$ \\
\hline 16 & Made in Penang Interactive Museum & 2013 & 193 & 4 \\
\hline 17 & 3D Glow in the Dark Museum & 2017 & 206 & 4 \\
\hline 18 & Penang Gold Museum & 2016 & 257 & 4 \\
\hline
\end{tabular}


Suraiyati Rahman and Sathish Velayuthan

Evolution and Diversification of Museum Function: Reflection of Market Demand in Penang, Malaysia

\begin{tabular}{|r|c|r|r|r|}
\hline Rank & Name of Museum & $\begin{array}{c}\text { Year } \\
\text { of Est }\end{array}$ & $\begin{array}{c}\text { Numbers of } \\
\text { Reviews }\end{array}$ & $\begin{array}{c}\text { Star } \\
\text { Rating }\end{array}$ \\
\hline 19 & Penang Ghost Museum & 2015 & 163 & 3.5 \\
\hline 20 & Asia Comis Cultural Museum & 2017 & 23 & 4.5 \\
\hline
\end{tabular}

Source: Secondary Data TripAdvisor

\section{CONCLUSION}

A world-recognised seal such as a World Heritage Site and strategic location in the city centre are the factors that contributed to the increased number of museums established as a tourism product. Market response towards the heritage tourism industry boosts the opportunity to commodify heritage resources into profitable products, such as museums. Results revealed that the trend of transformation in museum function has diversified and oriented towards consumer preferences. Social media platforms are the emerging marketing strategy in influencing technology-savvy users in sharing their reviews on museums' services and products. The transformation of museum roles in Penang has implications on the preservation of locality and cultural values as the primary role of museums. Despite the positive impact of creativity and collaboration among agencies, the implication on museums' interpretation was due to marketoriented products and boosting visits. The absence of state intervention and museology institutions to ensure the preservation of cultural traditions militate against non-commodifiable aspects, such as intangible cultural heritage, everyday practices and the spirit of a place.

\section{ACKNOWLEDGEMENT}

The author(s) would like to extend their appreciation to the Ministry of Higher Education, Malaysia for granting the Fundamental Research Grant entitled 'Establishing an Interpretation Model of Built Heritage Commodification for Tourism in Georgetown, Penang.' [Grant No. 203.PPBGN.6711405] that makes this study possible.

\section{REFERENCES}

Ab Samad, K., Shahidi, A.H, Rahim, A., Zuraidah, H. and Daeng H.J. (2012). Pendidikan Warisan di Muzium Malaysia Journal of Society and Spaces, 8(8), 35-48.

Ahmad, A. T. (2015). Penang Museums, Culture and History. Kajian Malaysia, 33(2), $153-174$.

Department of Museums Malaysia. (2017). Organization Chart. Retrieved June 14, 2017, from the Department of Museums Malaysia: Department of Museums Malaysia

Ahmed, Y. A., Ahmad, M. N., Ahmad, N., \& Zakaria, N. H. (2019). Social media for knowledge-sharing: A systematic literature review. Telematics and Informatics, 37, 72-112.

Álvarez, P., Dávila, P., \& Naya, L. M. (2017). Education museums: Historical educational discourse, typology and characteristics. The case of Spain. Paedagogica 
Historica.

Barbieri, L., Bruno, F., \& Muzzupappa, M. (2017). Virtual museum system evaluation through user studies. Journal of Cultural Heritage.

Brännback, M. (1999). The Concept of Customer -Orientation and Its Implication for Competence Development. Researchgate.

Chung, T. L., Marcketti, S., \& Fiore, A. M. (2014). Use of social networking services for marketing art museums. Museum Management and Curatorship.

Del Chiappa, G., Andreu, L., \& Gallarza, M. G. (2014). Emotions and visitors' satisfaction at a museum. International Journal of Culture, Tourism, and Hospitality Research.

Denzin, N. K., \& Lincoln, Y. S. (2006). The Sage Handbook of Qualitative Research, 2nd ed. Edited by Norman K. Denzin, and Yvonna S. Lincoln. Library.

Denzin, N. K., \& Lincoln, Y. S. (2008). Methods of Collecting and Analyzing Empirical Materials. Collecting and Interpreting Qualitative Materials.

Gilmore, A., \& Rentschler, R. (2002). Changes in museum management. Journal of Management Development, 21(10), 745-760.

Goulding, C. (2000). The commodification of the past, postmodern pastiche, and the search for authentic experiences at contemporary heritage attractions. European Journal of Marketing, 34(7), 835-853.

Hesseldahl, K., McGinley, C., \& Monk, G. (2018). Using design thinking to develop new methods of inclusive exhibition making. In Studies in Health Technology and Informatics.

Homadovski, A. (2009). Transformations in Cultural Institutions - Contemporary Museum Destinations and Influences of Industrial Branding Values. Prostor.

Koslow, J. (2019). Museums and digital culture: new perspectives and research. Museum Management and Curatorship.

Lee, H.-K. (2010). Role of museums in managing design education: a case study. International Journal of Education Through Art.

McCarthy, J., \& Wright, P. (2005). Time, place and technology in museums: A dialogical approach to the experience. Re-Thinking Technology in Museums: Towards a New Understanding of People's Experience in Museums.

McPherson, G. (2006). Public memories and private tastes: The shifting definitions of museums and their visitors in the UK. Museum Management and Curatorship.

Park, S.-Y., \& Vargo, S. L. (2012). The Service-Dominat logic Approach to Tourism Marketing Strategy. In: Strategic Marketing in Tourism Services.

Pitman, B., \& Hirzy, E. (2004). Art Museums in Transformation. Trust Magazine.

Schweibenz, W. (1998). The "“Virtual Museum"': New Perspectives for Museums to Present Objects and Information Using the Internet as a Knowledge Base and Communication System. In Internationalen Symposiums für Informationswissenschaft.

Shaharir, S. A., \& Zanuddin, H. (2018). Museum institutions in the digital age: The insights of Malaysian museums' use of Facebook. Journal of Social Sciences Research.

Sheng, C. W., \& Chen, M. C. (2012). A study of experience expectations of museum visitors. Tourism Management.

Stuedahl, D., Lowe, S. (2013). Design experiments with social media and museum 
Suraiyati Rahman and Sathish Velayuthan

Evolution and Diversification of Museum Function: Reflection of Market Demand in Penang, Malaysia

content in the context of the distributed museum. Nordes.

Volkert, J. (2019). The future of museum and gallery design: purpose process, perception. Museum Management and Curatorship.

Weilenmann, A., Hillman, T., \& Jungselius, B. (2013). Instagram at the museum: Communicating the museum experience through social photo sharing. In Conference on Human Factors in Computing Systems - Proceedings.

Received: January 2020. Accepted: $11^{\text {th }}$ May 2020 